\title{
A Case of Pyridoxine Dependent Epilepsy Presented with Status Epilepticus
}

\author{
Status Epileptikus ile Başvuran Pridoksin Bağımlı Epilepsi Olgusu
}

\author{
(1) Senem Ayça1', (1) Hamide Betül Gerik Çelebi2, (1) Sırrı Çam2 2, (1) Muzaffer Polat1 \\ ${ }^{1}$ Celal Bayar University Faculty of Medicine, Department of Pediatric Neurology, Manisa, Turkey \\ ${ }^{2}$ Celal Bayar University Faculty of Medicine, Department of Medical Genetic, Manisa, Turkey
}

\section{Abstract}

Pyridoxine-dependent epilepsy (PDE) is a rare autosomal recessive encephalopathy due to mutations in the ALDH7A 1 gene. Intractable seizures are the most frequent clinical form in the early infantile period. A case of a 4-month-old female patient presented to our hospital with status epilepticus. Her seizures started in the neonatal period and partial response to phenobarbital was seen. Her seizures could not be controlled with appropriate antiepileptic treatment. The seizure stopped with $100 \mathrm{mg}$ of intravenous pyridoxine administration. The diagnosis of PDE was considered and ALDH7A1 gene mutation analysis revealed homozygous missense mutation. Pyridoxine should be administrated in case of intractable seizures and should be included in status epilepticus treatment protocol. Diagnosis of PDE should be considered especially in our country where consanguineous marriage is frequently seen.

Keywords: Pyridoxine, epilepsy, status epilepticus

\section{Öz}

Pridoksin bağımlı epilepsi ALDH7A 1 geninde mutasyona bağlı gelişen otozomal resesif geçişli nadir görülen bir epileptik ensefalopatidir. Erken süt çocukluğu döneminde görülen dirençli nöbetler en sık gözlenen klinik formudur. Status epileptikus ile hastanemize 4 aylık kız olgu başvurdu. Nöbetleri neonatal dönemde başlayıp fenobarbitale kısmi yanıt görüldü. Uygun antiepileptik tedaviye rağmen nöbetleri kontrol altına alınamadı. Hastaya 100 mg pridoksin intravenöz olarak uygulandıktan sonra nöbeti durdu. Pridoksin bağımlı epilepsi tanısı düşünüldü ve yapılan ALDH7A1 gen analizinde homozigot missense mutasyon tespit edildi. Dirençli epilepsilerde ve status epileptikus tedavi protokolünde pridoksin uygulanmalıdır. Pridoksin bağımlı epilepsi tanısı akraba evliliğinin sık olarak görüldüğü ülkemizde özellikle düşünülmelidir.

Anahtar Kelimeler: Pridoksin, epilepsi, status epileptikus

\section{Introduction}

Pyridoxine-dependent epilepsy (PDE) (OMIM \#266100) is reported in 1954 for the first time. ${ }^{1}$ Prevalence has been estimated about 1 in 400.000 to $700.000 . .^{2}$ The related gene of this disorder, aldehyde dehydrogenase 7 family, member a1 (ALDH7A1) is mapped in the $5 \mathrm{q} 23.2$ chromosomal location and consists of 18 exons. The ALDH7A1 gene encodes antiquitin enzyme that plays a major role in the detoxification of aldehydes generated by alcohol metabolism and lipid peroxidation. Antiquitin functions as a L-1-piperidine-6carboxylate (P6C)/ $\alpha$-aminoadipic semialdehyde ( $\alpha$-AASA) dehydrogenase. When antiquitin activity reduces, pipecolic acid, AASA ve 1-piperidin-6- carboxyilate accumulate. ${ }^{3}$ These accumulated carboxyilate forms reduce the functioning of pyridoxal-5-phosphate in brain. In the case of classical PDE, seizures start shortly after birth and mostly in first hours. Classic clinical findings characterized by abnormal intrauterine movements, intractable seizures that are not controlled with antiepileptic drugs, developmental delay and response to the pyridoxine treatment. In this report, we present a patient diagnosed PDE with status epilepticus.

\section{Case Report}

A baby girl was delivered to a consanguineous family via normal spontaneous vaginal delivery with the obstetric history G1 P1 L1 A0 at 38 weeks with 8/9 APGAR scores. In first two days of her life, generalised clonic seizures was detected at another clinic and partially controlled with 5

Address for Correspondence/Yazışma Adresi: Senem Ayça MD, Celal Bayar University Faculty of Medicine, Department of Pediatric Neurology, Manisa, Turkey Phone: +90 5557086323 E-mail: senemkaleci85@gmail.com ORCID ID: orcid.org/0000-0001-7486-9655

Received/Geliș Tarihi: 21.11.2017 Accepted/Kabul Tarihi: 23.01.2018

${ }^{\circ}$ Copyright 2019 by Society of Pediatric Emergency and Intensive Care Medicine

Journal of Pediatric Emergency and Pediatric Intensive Care published by Galenos Yayınevi. 
$\mathrm{mg} / \mathrm{kg} /$ day of phenobarbital treatment. At the age of 4 months she presented with status epilepticus. After two doses of rectal diazepam, treatment with loading dose of 20 $\mathrm{mg} / \mathrm{kg}$ phenytoin and $40 \mathrm{mg} / \mathrm{kg}$ levetiracetam didn't stop the seizures, midazolam infusion was started and she was intubated. Electroencephalography (EEG) displayed multifocal sharp spike waves. Despite giving high doses of midazolam infusion the seizures didn't controlled. After injection of 100 mg pyridoxine intravenously, seizures dramatically stopped. Before the treatment of pyridoxine neurological examination revealed axial hypotonia. There was no eye contact and eye tracking. Other systemically examination was normal. A few days after seizures stopped, eye contact and tracking have started and muscle tonicity was normal. Cranial magnetic resonance imaging and magnetic resonance imaging spectroscopy were normal. Control EEG displayed second day of seizures stopped, revealed normal features. Biochemical studies were normal. Blood ammonia, lactate, urine organic acids, blood acyl carnitine and quantitative blood amino acid levels were normal. With the diagnosis of PDE; ALDH7A1 gene sequence analysis including all coding exons and exonintron boundiries was done with inhouse designed primers and ALDH7A1 NM_001182.4:C.1232C>T; (p.Pro411Leu) homozygous missense mutation was detected. This mutation was previously reported. In silico analysis with mutation taster, SIFT, Polyphen 2 predicted this variant as a disease causing mutation. Currently, the patient's pyridoxine treatment 200 $\mathrm{mg} /$ day orally continues. There was no seizure detected after pyridoxine treatment and antiepileptic drugs were stopped. Her neurological examination in the eighth month were normal. Denver developmental screening test was compatible with her age.

Written informed consent was obtained from the parents of the patient.

\section{Discussion}

PDE is caused by a mutation in ALDH7A1 gene encoding antiqutin. The alpha-aminoapidic semialdehyde dehydrogenase enzyme, known as antiquitin, is responsible for the catalysis of the alpha-aminoapidic acid conversion of the alpha-aminoapidic semialdehyde and distrupts the enzyme's "defect" activity. PDE due to antiquitin insufficiency is a cause of curable epilepsy and cognitive impairment. ${ }^{4}$ Hypotonicity, hypertonicity, dystonia, irritability, lethargy and encephalopathy can be observed as neurological signs. They may present with different seizure types such as partial, generalized, clonic, tonic, myoclonic, infantile spasm and status epilepticus. ${ }^{5}$ In our case, partial clonic seizures started on postnatal second day. Partial response to phenobarbital caused a delay in diagnosis until she presented with status epilepticus at four months of age. Cranial imaging findings are usually normal, but various findings such as corpus callosum hypoplasia, dysplasia, hemorrhage, ventriculomegaly, cortical atrophy can also be observed. ${ }^{6}$ These findings may lead to missed PDE diagnosis or misdiagnosis. The definitive diagnosis was established by mutation in the ALDH7A1 gene in the molecular study p. P411L (c.1232C>T) homozygous missense amino acid mutation was detected, within a highly conserved region throughout species.

In familial segregation, it was shown that the mother and father had p. P411L (c.1232C> T) heterozygous variation in the ALDH7A1 gene. Parents were evaluated as carriers for this mutation. For each subsequent pregnancy, prenatal preimplantation diagnosis was suggested to the family.

While a variety of EEG abnormalities such as deterioration on the ground rhythm, various paroxysmal activities and normal interictal EEG, have been described in individuals with PDE, none is pathognomonic for this disorder. ${ }^{7-9}$ Even though PDE is characterized by intractable seizures in prenatal or neonatal onset and status epilepticus, PDE should be considered as a cause of either intractable seizures presenting in children up to the third year of life for which no identified underlying lesion or partially responsive to antiepileptic drugs. ${ }^{10}$ Pyridoxine should be given especially in infants when status epilepticus can not be controlled with antiepileptic drugs. This has caused the diagnosis to be made clinically. At the same time, all unexplained infant epilepsies should be evaluated as antiquitin insufficiency. Despite early treatment in PDE, developmental delay was reported in $70 \%$ of the cases. ${ }^{5}$ Patients showed deterioration of neurocognitive functions within 6 years, especially in verbal reasoning skills, information processing speed and math and reading comprehension. ${ }^{11}$ This would suggest a possible slowly progressive neurodegenerative disease course of PDE caused by ALDHTA 1 genetic defect. This may be a cause of pyridoxine monotherapy does not normalize the accumulation of a-aminoadipic acid semialdehyde and pipecolic acid levels in the central nervous system. Despite no clinical seizures, normal EEG and demonstration of normal Denver development testing score, she might have neurodevelopmental abnormalities recognized after school entry. Long-term treatment outcome reports will increase our knowledge about natural history of the disease. In conclusion, in our country where consanguineous marriage is frequent, treatment with pyridoxine should be kept in mind for all intractable epilepsy and status epilepticus and pyridoxine should be given. ALDH7A1 gene molecular analysis should be considered in infants who had complete or partial response to pyridoxine treatment. The moleculer analysis can be helpful in genetic counseling, prenatal diagnosis, and early treatment for patients with PDE. 


\section{Ethics}

Informed Consent: Written informed consent was obtained from the parents of the patient

Peer-review: Internally peer-reviewed.

\section{Authorship Contributions}

Design: M.P., Analysis or Interpretation: S.Ç., M.P., Literature Search: H.B.G.Ç., S.A., Writing: S.A., H.B.G.Ç.

Conflict of Interest: No conflict of interest was declared by the authors.

Financial Disclosure: The authors declared that this study received no financial support.

\section{References}

1. Hunt AD Jr, Stokes J Jr, Mcrory WW, Stroud HH. Pyridoxine dependency: report of a case of intractable convulsions in an infant controlled by pyridoxine. Pediatrics. 1954;13:140-5.

2. Bennett $\mathrm{CL}$, Huynh HM, Chance PF, Glass IA, Gospe SM Jr. Genetic heterogeneity for autosomal recessive pyridoxine-dependent seizures. Neurogenetics. 2005;6:143-9.

3. Mills PB, Struys E, Jacobs C, Plecko B, Baxter P, Baumgartner M, et al. Mutations in antiquitin in individuals with pyridoxine-dependent seizures. Nat Med. 2006;12:307-9.
4. Gospe Sm Jr. Pyridoxine-dependent seizures: new genetic and biochemical clues to help with diagnosis and treatment. Curr Opin Neurol. 2006;19:148-53.

5. van Karnebeek CD, Stockler S. Treatable inborn errors of metabolism causing intellectual disability: a systematic literature review. Mol Genet Metab. 2012;103:368-81.

6. van Karnebeek CD, Tiebout S, Niermeijer J, Poll B, Ghani A, et al. Pyridoxine-Dependent Epilepsy: An Expanding Clinical Spectrum. Pediatric Neurology. 2016;59:6-12.

7. Gospe SM Jr, Hecht ST. Longitudinal MRI findings in pyridoxine dependent seizures. Neurology. 1998;51:74-8.

8. Bok LA, Maurits NM, Willemsen MA, Jakobs C, Teune LK, et al. The EEG response to pyridoxine-IV neither identifies nor excludes pyridoxine dependent epilepsy. Epilepsia. 2010;51:2406-11.

9. Mikati MA, Trevathan E, Krishnamoorthy KS, Lombroso CT. Pyridoxine-dependent epilepsy: EEG investigations and long-term follow-up. Electroencephalogr Clin Neurophysiol. 1991;78:215-21.

10. Stockler S, Plecko B, Gospe SM, Coulter-Mackie M, Connolly M, et al. Pyridoxine dependent epilepsy and antiquitin deficiency: clinical and molecular characteristics and recommendations for diagnosis, treatment and follow-up. Mol Genet Metab. 2011;104:48-60.

11. Nasr E, Mamak E, Feigenbaum A, Donner EJ, MercimekMahmutoglu S. Long-Term Treatment Outcome of two Patients With Pyridoxine-Dependent Epilepsy Caused by ALDH7A 1 Mutations: Normal Neurocognitive Outcome. J Child Neurol. 2015;30:648-53. 